\title{
雜
}

坏

南方のチタン白 重要物資之しての硼砂需給は保有數量の漸減之共

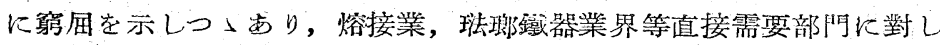
不安を與へてるる䁈情汇鑑み，商工省化學局ではかねて不足物資對策 協議會, 工業試驗所等關係機關を動員これが代用物資を研究してるた が，最近に至り東亞共榮圈內に䁷富化賦存する原碃より製出するチタ シ白が硼砂代用として頗る優良で市るととが明磪となり，特て焀接業 向としては殆ど完壁に近い性能を有するととが筫地試驗によつて立證 さるるに至り關係業界の期待を集めてるる.

郎ち嗍砂の需給關保は硓酸と共に主原料たる南米物原鐄の輸入杜絕 し最近では武田長兵㒀商店，監野義商店等が賞局指示に基いて限られ た保有量を管理，超重點主義の喰延し方針を執つて居り，代用品探求 は焦眉の課題として要請されてるたものである.

今包代用價值充分の折紙をつけられをチタン白は現在チタン工業, 堺化學，杤木化學，日本砂鐵等各社が主要製造業者で需給關係も決し て樂觀は許さないが, 當面喫緊事たる焀接業界に對し從來の嗍砂供給 量に相當する位の量を振向けることは䀦施上さしたる困難はない模樣 であり，配給查定上の行政措置によつて解決し得る見达である。

理藻土工組結成 日本珪藻土工業組合聯合會結成準确委員會 ゙゙は 1 月 18 日正午大阪洗屋橋美津濃に同會結成促進協議會索開催, 工聯設 立具體策, 輸送對策並に包裝容器加工策等に就き種々討議したが右は 珪藻土が現下に於ける主要物資として石油觸媒, 重油濾過その他各種 保溫劑等に不可缺なるに鑑为生產垈强之需給の計畫化を圖るため各ブ ロック別工組の設立を進展せしめると共にとれと併行的に同會結成を 促進せんとしてるるるのである．而して一方これが結成の側面的促進 を圖るため同委員會では更に企畫院化對し重要物資指定方を陳情する こと〉なつをが, 右輸䢪對策並に包裝材料磪保策樹立が先決問題であ 3 .

なほ聯合會釒下のブロック別工組中宮城地區（北海道及び東北 6 縣 を含む) 大分地區(九州一四) は既に設立し着々業㹣を逐行してるる

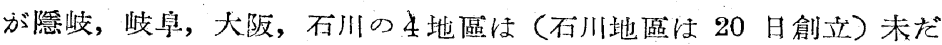
準请途上にあって㓣王迄にはな活時日を要する狀態にあり，同委員會 では右對策が具對化すると共代未設定地區门嶫する工組㓣立促進策を む同時に溝ずべく攻究中であり大體 2 月中には各地區別工組の結成を 完了せしむる豫定である。

陶磁器配給會动陶磁器工業の企業整确は全國的に展開され各地區 工業聯合で新統合體設应計畫書を作成して居り，3，4 月頃には完了 する見达であるが日陶聯では整碚完了後に於ける陶磁器配給統制會社 を設立する計畫を進めてるる。即ち現在日陶聯加入工業組合は70 餘 あり企業整碏により著しく縮小するが日陶聯では元卸並に卸商業組合 经下の配給業者を子參加させ販賣製造の雨部門を合して配給続制會藏 を設立せんとしてるる。

なほ日陶聯では統制のため昨年土建及び新興陶磁器儿對しそれぞれ 統制會社(兩社とも資本金 100 萬嘪) 設立したが今包飲食器，火鉢 その他を合した統制會社を設立せんとしてをり陶磁器界の配給機構確 立はやらやく軌道に乘らんとしでるる。

タイル, 福生陶器の一元統制䔈施 土木建築陶器統制株式會社では 新春々共に愈々本格的業務突開始すること」なり 2 月 8 日を期して まづタイルと䱣生陶器の生產, 配給を通ずる一元的統制を開始する。 な海管は日下手續中心中央图決定走待与 3,4 月頃出ら計畫配給に 着手する豫定でこれ等配給計畫は何れる 產地每に配給協議體を組織し
その運營の圓滑を期してるる。

耐火煉瓦の重點生産 耐火煉瓦工業は 17 年下期飞於いて石炭割當 の大幅㓩減を受けてるるので著しい操短を行つてるるが, 18 年度に 於いても不炭割當は必ずしも樂觀を許さない貫情にむるので生產合理 化策としての生產統制の强化は必至となつた。

統制の衝に當る耐火煉瓦工聯では石炭配給に就いては現在迄のとと ろ貫績主義を取つてるるが生產低下をこの鰮放置する㩐には行かず， 何等かの具體策を講ずる模樣である。

生產合理化筑としては重點主義が先づ考へられるが斯る强行手段は 至難と見られてみる゙，同業界は製品の公價問題も未だ落着せず，他方 に於いて販賣続制も統制會社の設立を見ない現狀にするので企業整䂷

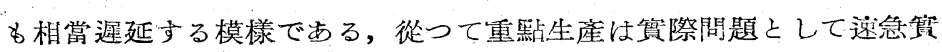
現は期待出來ず，生產合理化の暫定策として生產統制强化策を行子も のと見られる.生產統制の强化は販賣統制, 公價改言, 檢査所設置等

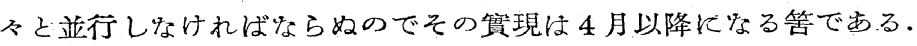

耐火煉瓦の園滑配給 耐火煉瓦の四滑楜正な配給を期するねめ，商 工省では䠶報の如く耐火煤瓦配給統制規則を公布すへく準嘴を進めて 居り，己れに伴子日本耐火煉瓦配給統制株式會社（資本金 300 萬四全 額拂达)の設立については附火煉瓦工聯を中心に大體の創立準确を終 へ，近く設立するてとに決定してるるが，當局では更に合理的配給對 策を護ずるをめ配給統制規則の䁈施と共に需瑟者團體を含めて耐火煉 瓦需給協議會(假稱) を工聯內又は配給會芘（前記）內飞設置する模 樣である。

需給協議會には最大需要者たる鐵鋼統制會を初め化學工業關係の需 要者團體を包含して需要者側の型望を容れて筫情に郎した圆滑，適正 な配給を行ふことを目的とする，又需要者側の希望する質と量とを筫 際の生產能力之睍み合せて合理的生產計畫を樹立する。

從つて闰拹議會は生產部門に對してる可なり强い制約を加一得る譯 で，一般に懸念してるる配給統制筫施後の品質低下, 低級規格品の濫 造等は同脇議會によつて封鋇するととっなり，業界の明朗性を期する ことにならら。

なほ同協議會の發足は配給統制々並行して設置する模栐なので, 18 年度の推定需要量に對しては再檢討を加一て 18 年度配給計畫を若干 變更するものと見られる。

硝子界の企業整備終る 确子工聯は長期戰に對㕍するをめ 16 年 10 月 4 日碑子企業整碳要綱の發表々同時に着々之整硣の準储に取掛つて 以來約 1 年 3 ケ月この間商工省をはじめ全國各地區の确子工組の指 導により企業整備の全面的完結を見るとと〉なり，2月一杯には諸手 續を終一劃期的䂤子工業生產增强體制を整へること〉なつた。全國の 企業體は小企業を合すると從來約 800 名近くを數へたが整碚完了の曉 は80 餘名程度に縮少する見达で，未だ全國的統計はないが東京确子”

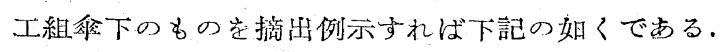

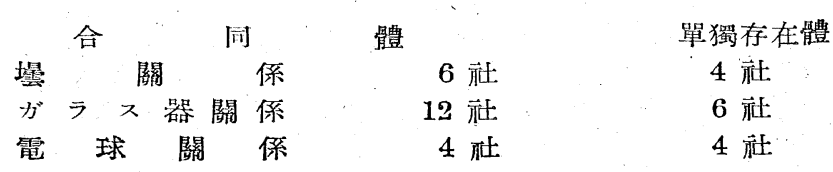

單獨存在體の社名を列記すれば

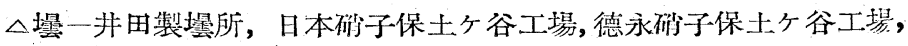
同川崎工場, キリンビール川崎工場, 同橫瀆製䭪工場

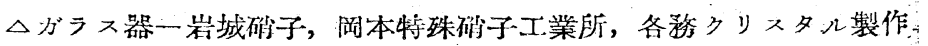


所，小絲製作所，日本硬質确子製造所，岩田藤七(工藝确子) $\triangle$ 電球一東京芝浦電氣マッダ支社, 理研眞空大多喜工場, エビス電 球大森工場, 中外電朵產業橫濱工場 (但乙溫庞計, 量器計關 係の業者中單獨存在神は未定であるが大體 $5 ， 6$ 工㻛となる 筈である)

合同體の新社は何れも企業許可を待つて，資金認可を申請中であり 東京地區では 2 月中旬頃までには新形體を整へる段取りとなつてる る.

言ふ迄もなく企業整碏の基準ま整硙要綱に明示してるる通りである が，确子工業の中でも製嚗業者の整備に當つてはその特殊性に鑑》單 蚫存在體は特に自衝製嚗器の所秲者を重點とし, 合阿體の場合もとの 方針の下に整俏を進めた。がラス器, 電球の 2 種では特殊製品整浩業

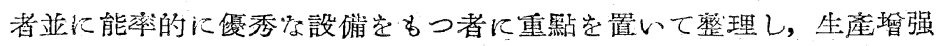
の一翼をらしむると同時に特殊技能の强化育成に努めてるる。

企業整碏によつて生產增產の新段階を劃すとと〉なつたが周知の如 く資材難は今後益々逼迫を餘儀なくする事態にあり，生產合理策は極 废の重點生產を要請する運命にあるので今回の企業整備を以て最後段 階の整偳と云子譯には行かない，原材料難亚に資材難の波校は單に确 子工業のみに限つを事ではないが，その要因をる輸送蜼は戰時體制に 附隨する必然的結果として好むと否とに拘らず生產機構を變革しつ」

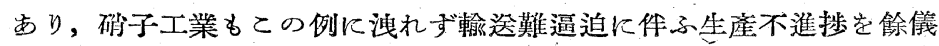
なくしてるる、然るに第一段階の企業整備とも云ふべき包の整備は 何等輸揆關係々の睍み合せを行つてるない，果しててれを企業整備の 根本的解決と見做し得ない理由である。

だが今包の企業整備は從來の自由主義的考人方を一擲し, 生產方式 に新な観點を與以ることに役立つばかりでなく, 業界の單純化を斷行
し極度の厴縮を强行した點て劃期的である．今後進むべき業界に新た な指針を與へたと云へなら。

企業整備と並行して其販問題は重要となり, 确子工聯儿共販部を設 置するか, 共販會社として獨立するかの分伖點に立つてるるが, 企業 整備の完結と共に配給部雏をる共販問題も近く圆滿解決を見ることに なら5.かくて生產から配給消費に至る全面的統制は完結し，4 月前 後には戰時體制に郎する業界の新をな發足を見ることうならら。

建築用板硝子の配給統制商工省では豫て建築用板确子飞對し配給

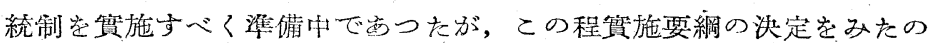
で化學，企業兩局長連名を以て同品を木造建物建築統制規則第八條化

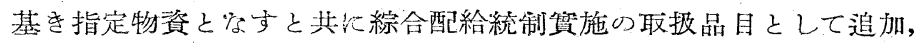

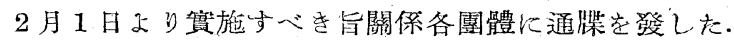

配給方法他他の指定物資闰樣各庥縣建築課他於いて建築認許可あり をるものに限り需要申請售を受理, 查定の割當證明書を發行する。

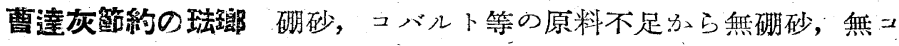
バルト珐瑯の製作を行ふととになつたが更に班瑯の原料をる确石, ソ 一ダ灰を枢力節減した珐瑯の製作について商工行大阪工業試驗所中西 技師が研坣中のところ最近に至つて小試驗體について成功したので引 續き目下大試驗體决いて研究を進めてるる。

ソーダ灰の節減は從來 $30 \%$ 程度を要したものを $5 \%$ 程度にまで 所用量の切下げを行はんとするものであり，乙の結果諸原料の制限か。

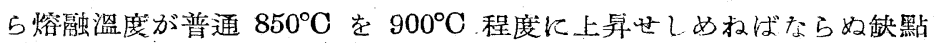
があるのでこれが盜度引下げを考虑してみる。

なほ化學工業方面に必要とする耐酸泆瑯については泆瑯の上にさら

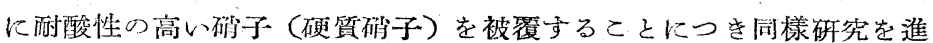
めてるる。

霉

\section{替助會員入會 者}

却

$$
\text { 名任所 }
$$

昭和䈍業株式會社札䖧卞南大通西 8 の 1

\section{特别會員入會省}

氏 名 住所勤務先, 職業

井上隆一 石川影江沼郡大聖寺町字仲町 10 九谷燒製造唄寒

村田 八束 名占屋古昭和區東榮町 7 の 18 日本碍子粎式會社

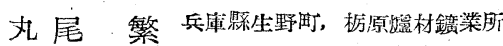

歰願”一郎支那天津西宮島街 1 丁目, 水信确子整造業

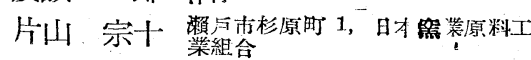

清浦 雷作 東京古大森温田㕑調布４の 51

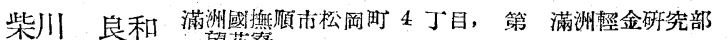

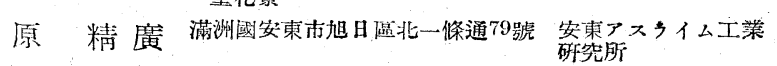

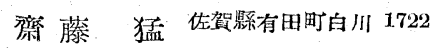

香蘭合名會社

\section{正會員入會者}

和田可三四 名古屋古南區呼繶町朝程 17

野々村政利山形市七日市

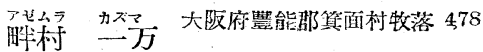

梅田 俊平 兵庫縣武庫郡㕷尾村八ッ松 2 の 6

高自 富郎濑今活仲洞町 8
鹿島 次郎 東京市㗅野川區田端町 650

武田 卓三 朝䱢威南興南邑柳亭里, 德明察56

野村 三治赫的 濑戸市東吉田町 66

秋元 義郎 東京本淀橋區十二社 320 , 小西六

杉本 清道 北海道空知郡㳻川町, 北海道人造 鈴木 武雄 大阪市北區北同心町 2 の 50 の 1 池田，孝雄 朝鮮咸南興南邑枷宗里, 獽明察

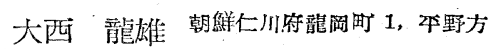

品本 美見大阪市港區入船町 1 の 8

山形達男 東京析蒲田區矢口町 809 , 東光電 長島一郎川崎古堀川町, 東京芝浦電氣、ッ 岡見介靖大阪市此花冨息屋町 249 , 住友金 介端屬工業株圷會社製鍓所研究所

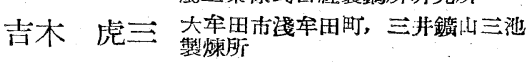
湯川，利夫 和歌山䅫日高郡由良村横渞 秀實 ${ }_{201}^{2}$ 歌山堵日高郡由良村大字阿户 佐々木利雄 東京古荒川區日暮里町 2 の 54 名古屋製䧝鳴海工場 今书 忠夫 山形縣立工業試驗場 榎本 修二 辻本一男

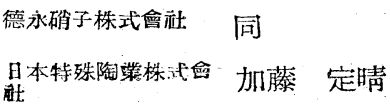

楅本 喜次 東京市豐島區雜司ヶ谷 6 の 913，

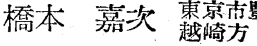

加藤 道夫 岐卓夥土岐郡古, 会村日向

植野儀三郎 懒戶市大字今 2093

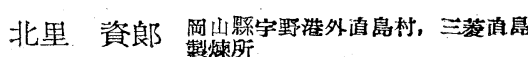

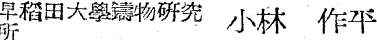

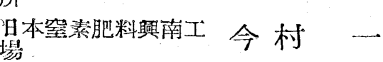
爱知貼震業學校 永塚 樂治 秋山 桂一 同

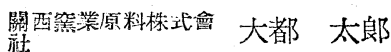
昆本窒素肥洲與南工 黑田 泰造 鐵道局建没䛇同 島田确子製造所同 同 同 同 遠藤 隆雄 岩崎宇三郎 小野田セメント由良 工場 日本光學工業株烒俞長枝 春本 同上同

同上同

製陶業 加藤不二男 濑戸陶器有限會社 鈴木 舜二: 能倉左武郎 